\title{
Bioactivity of Five Essential Oils Against Bruchidius incarnatus (Bohemann, 1833)
}

\author{
Hany Ahmed FOUAD \\ Sohag University, Faculty of Agriculture, Plant Protection Department, 55 El-Kawther Street, Sohag, Egypt; haafouad@yahoo.com
}

\begin{abstract}
In the world, the faba bean beetle Bruchidius incarnatus (Coleoptera: Bruchidae) is an important insect-pest, especially on faba bean Vicia faba (Leguminosae) and it can infest field crops and cause severe damage in storage. Essential oils can be an alternative method to synthetic insecticides for pest management, due to their efficiency and environmental safety. The aim of the current study was to evaluate the toxicity and repellent activity of essential oils of camphor (Eucalyptus globules), castor (Ricinus communis), cinnamon (Cinnamomum zeylanicum), clove (Syzygium aromaticum) and mustard (Brassica rapa) against B. incarnatus adults. The treatments which contained essential oils at 0.5, 1, 2 and 4\% and acetone (control) were applied. All essential oils with 4\% concentration repelled the $B$. incarnatus adult except castor oil. The percentage of repellence was higher when used essential oil of cinnamon with 2 and $4 \%$ concentration compared with other essential oils and concentrations. In residual film experiment, the cinnamon oil had the highest toxicity rate on $B$. incarnatus adult fallowed by clove, camphor, mustard and the lowest effect was by castor oil. Based on our results, I can conclude that essential oils of camphor, cinnamon, clove and mustard have potential for use in the integrated management of $B$. incarnatus adult.
\end{abstract}

Keywords: botanical insecticides, essential oil, faba bean beetle, repellency, storage grains, toxicity

\section{Introduction}

The faba bean beetle, Bruchidius incarnatus (Coleoptera: Bruchidae) is associated with faba bean storage, where it can attack the whole faba bean grains in field and storeroom. Traditional organophosphates, such as malathion and pirimiphos-methyl are the most commonly used residual insecticides in stored grains (Arthur, 1996; Santos et al., 2009). Chemical insecticides can cause pest resistance, environmental and food contamination and toxicity to non-target organisms (Pimentel et al., 2009; Tavares et al., 2010). Plants produce secondary metabolites many of which can have insecticidal properties, as an alternative to synthetic insecticides (Potenza et al., 2004). Plant extracts and essential oils have traditionally been used to kill or repel stored product insects (Arabi et al., 2008; Fouad et al., 2012; Tapondjou et al., 2005; Tinkeu et al., 2004). The insecticidal constituents of many essential oils against stored product insects are mainly monoterpenoids such as limonene, linalool, terpineol, carvacrol and myrcene (Ahn et al., 1998; Regnault-Roger and Hamraoui, 1995). Essential oils of several medical plant displayed considerable toxic, fumigant and repellent effects on adults of Bruchidae family (Mahfuz and Khalequzzaman, 2007; Mahmoudvand et al., 2011; Sabbour and Abd-El-Aziz, 2010).

The objective of this study was investigation the adulticidal of essential oil of camphor (Eucalyptus globulus), castor (Ricinus communis), cinnamon (Cinnamomum zeylanicum), clove (Syzygium aromaticum) and mustard (Brassica rapa) plants on $B$. incarnatus adult.

\section{Materials and methods}

\section{The insect}

Parent adults of faba bean beetle, Bruchidius incarnatus were obtained from laboratory stock cultures maintained at plant protection department, Faculty of Agriculture, Sohag University, Sohag, Egypt. They were reared in an environmentally controlled room at $25 \pm 2^{\circ} \mathrm{C}, 70 \pm 10 \%$ relative humidity $(\mathrm{RH})$ and darkness. The food media used was whole faba bean grains.

\section{Essential oils}

The essential oils of camphor (Cinnamomum camphora), castor (Ricinus communis), cinnamon (Cinnamomum zeylanicum), clove (Syzygium aromaticum) and mustard (Brassica rapa) were purchased from an commercial company (Obour City, Egypt).

\section{The repellency test}

The test was done in Petri dishes ( $9 \mathrm{~cm}$ diameter), containing filter papers inside (Whatman $\mathrm{N}^{\circ} 1,9 \mathrm{~cm}$ diameter) in the dimension of the dishes. Solutions were prepared at concentrations of $0.5,1,2$ and $4 \%$. On one half of filter paper, uniformly, $0.5 \mathrm{~mL}$ of each concentration of the essential oils was applied, and on the other half only acetone 
was applied. The treated and control half-discs were left at 10 minutes for the solvent to evaporate. On the center of each dish, 10 newly unsexed adults of $B$. incarnatus were placed. The treatments were repeated ten times. The repellency assay was placed in an environmentally controlled room at $25 \pm 2^{\circ} \mathrm{C}, 70 \pm 10 \% \mathrm{RH}$ and darkness. The number of beetles present in the control half (NC) and the treated half (NT) were recorded after 2 and 4 hours (h) (OliveroVerbel et al., 2010).

\section{Contact with a treated surface}

Using a precision microsyringe, one $\mathrm{mL}$ of either each oil solution at $0.5,1,2$ and $4 \%$ or acetone (control) was applied to the surface of a Petri dish $(9 \mathrm{~cm}$ diameter, surface $63.6 \mathrm{~cm}^{2}$ ) corresponding to dosages of $0.08,0.16,0.32$ and $0.64 \mu \mathrm{L}$ of oil $/ \mathrm{cm}^{2}$. Each dish was left without direct sunlight for $10 \mathrm{~min}$, after which 10 newly unsexed adults $B$. incarnates were placed in each one. The dishes were closed with a glass cover and kept in an environmentally controlled room $\left(25 \pm 1^{\circ} \mathrm{C}, 70 \pm 10 \% \mathrm{RH}\right.$ and darkness $)$. The mortality (\%) was evaluated 24, 48, 72 and $96 \mathrm{~h}$ after starting the test (Tapondjou et al., 2005).

The design was entirely randomized with five oils with five concentrations and ten replications for each, with 10 adults of $B$. incarnates for each replicate. Data obtained were corrected using Abbott's formula (1925).

\section{Statistical analysis}

The data from the toxicity of the essential oils on contaminated surfaces were calculated using PROBIT analysis (Finney, 1971). The median lethal dose $\left(\mathrm{LD}_{50}\right)$ was obtained by PROC PROBIT model using SAS software (SAS Institute 2002). The data of repellent test were compared by the paired t-test at $5 \%$ probability using SAS software (SAS Institute, 2002). The percentage of repellency $(\mathrm{PR})$ values were classified into classes of repellency $0, \mathrm{I}, \mathrm{II}$, III, IV or V, where, class $0(P R \leq 0.1 \%)$, class I $(P R=0.1$ $20 \%)$, class II ( $P R=20.1-40 \%)$, class III $(P R=40.1-60 \%)$, class IV $(P R=60.1-80 \%)$ and class V $(P R=80.1-100 \%)$, and negative PR values were treated as zero (Juliana and Su, 1983; Obeng-Ofori and Reichmuth, 1997; Benzi et al., 2009).

\section{Results and discussion}

Percentages of repellence (PR) values are shown in Fig. 1, Fig. 2 and Tab. 1. Four essential oils exhibited repellent activity against $B$. incarnates adult after 2 and 4 h. Data

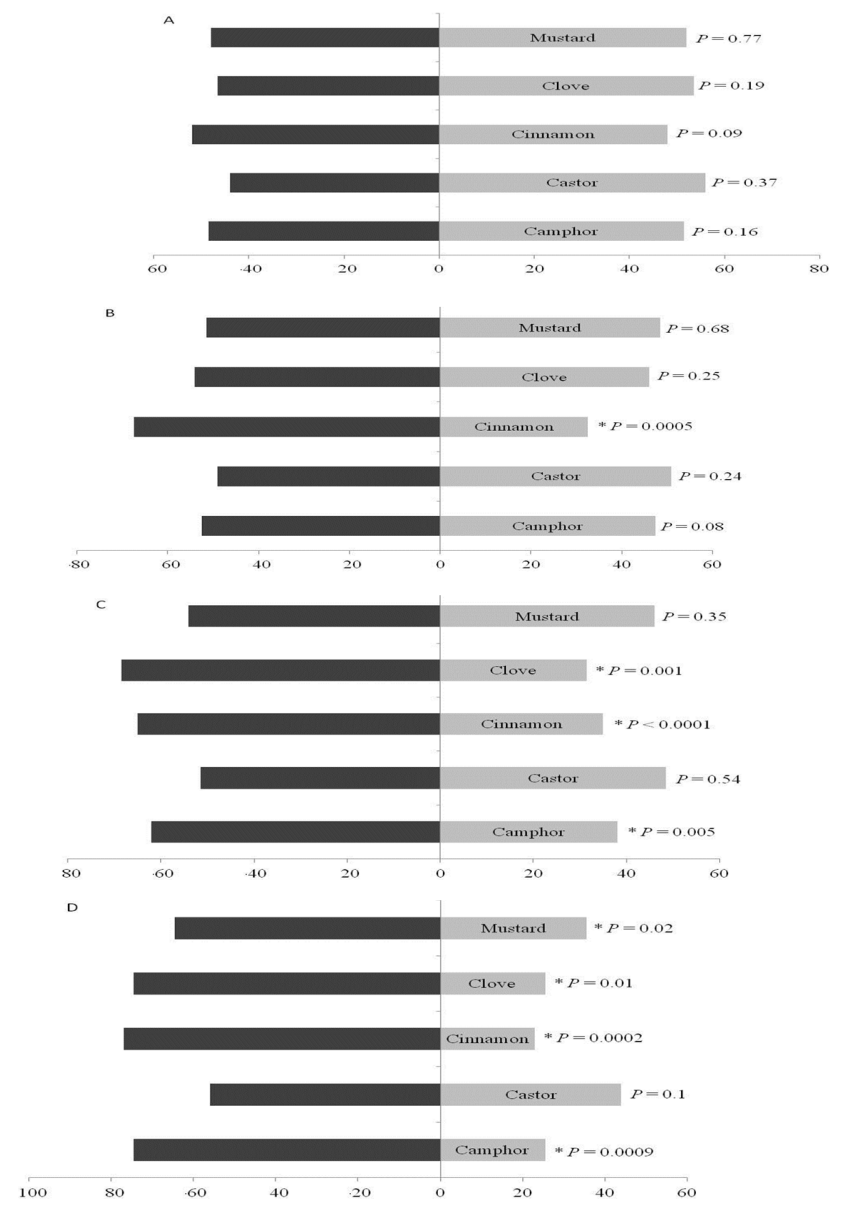

Fig. 1. Preference (\%) of Bruchidius incarnatus for a half filter paper treated or not with five essential oils with concentrations (A) 0.5 $\%$ (B) $1 \%, 2 \%$ and (c) $4 \%$ after $2 \mathrm{~h}$, in free choice test. ${ }^{*}$ Significant values at $5 \%$ probability by t-paired test $(p<0.05)$ 
Tab. 1. Mean percent repellency (PR) values for five essential oils tested on adults of Bruchidius incarnatus (Coleoptera: Bruchidae) in free-choice test

\begin{tabular}{|c|c|c|c|c|c|c|c|c|}
\hline \multirow{2}{*}{ Essential oils $\quad$ Concentrations } & \multicolumn{4}{|c|}{ After 2 hours } & \multicolumn{4}{|c|}{ After 4 hours } \\
\hline & $0.5 \%$ & $1 \%$ & $2 \%$ & $4 \%$ & $0.5 \%$ & $1 \%$ & $2 \%$ & $4 \%$ \\
\hline Camphor & $13 \mathrm{I}$ & $21 \mathrm{II}$ & $30 \mathrm{II}$ & $44 \mathrm{III}$ & 0 & $5 \mathrm{I}$ & $24 \mathrm{II}$ & $49 \mathrm{III}$ \\
\hline Castor & $4 \mathrm{I}$ & $8 \mathrm{I}$ & $3 \mathrm{I}$ & $18 \mathrm{I}$ & 0 & 0 & $3 \mathrm{I}$ & $12 \mathrm{I}$ \\
\hline Cinnamon & $18 \mathrm{I}$ & $55 \mathrm{III}$ & $65 \mathrm{IV}$ & $63 \mathrm{IV}$ & $4 \mathrm{I}$ & $35 \mathrm{II}$ & $30 \mathrm{II}$ & 54 III \\
\hline Clove & 0 & $12 \mathrm{I}$ & 43 III & $36 \mathrm{II}$ & 0 & $8 \mathrm{I}$ & $37 \mathrm{II}$ & $49 \mathrm{III}$ \\
\hline Mustard & $4 \mathrm{I}$ & $11 \mathrm{I}$ & $27 \mathrm{II}$ & $37 \mathrm{II}$ & 0 & $3 \mathrm{I}$ & $8 \mathrm{I}$ & $29 \mathrm{II}$ \\
\hline
\end{tabular}

Note: Classes of Repellency: class I (PR = 0.1-20\%), class II (PR = 20.1-40\%), class III (40.1-60\%);

Negative PR values were treated as zero

in Tab. 1 showed that cinnamon oil had generally a more effective repellent (63\%) after $2 \mathrm{~h}$ against adult $B$. incarnatus. However, castor oil had less PR values in all concentrations been used. The rest of essential oils had a moderate repellent action. A non significant difference showed between the essential oils with $0.5 \%$ concentration against $B$. incarnates after 2 and $4 \mathrm{~h}$ of treatment. In generally, the efficacy in respect of the repellency followed in the order: cinnamon $>$ clove $>$ camphor $>$ mustard $>$ castor.

The classes of repellency were higher with the cinnamon oil at $4 \%$ (classes IV) after $2 \mathrm{~h}$ of treatment compared with those from essential oils and other essential oils at 0.5 , 1 and $2 \%$ (classes III, II and I) (Tab. 1).

The $\mathrm{LD}_{50}$ for $B$. incarnatus beetles was recorded after $24,48,72$ and $96 \mathrm{~h}$ from the beginning of treatment (Tab. 2). The essential oils from all five medical plants increased the mortality of the $B$. incarnatus adults. The $\mathrm{LD}_{50}$ was decreased gradually in all the essential oils with increasing the days of exposure. Cinnamon oil revealed the highest residual toxicity effect followed by clove oil, camphor, mustard and the lowest effect was recorded in case of castor oil.

Our results showed that four of the tested essential oils (cinnamon, clove, camphor and Mustard) had a significant

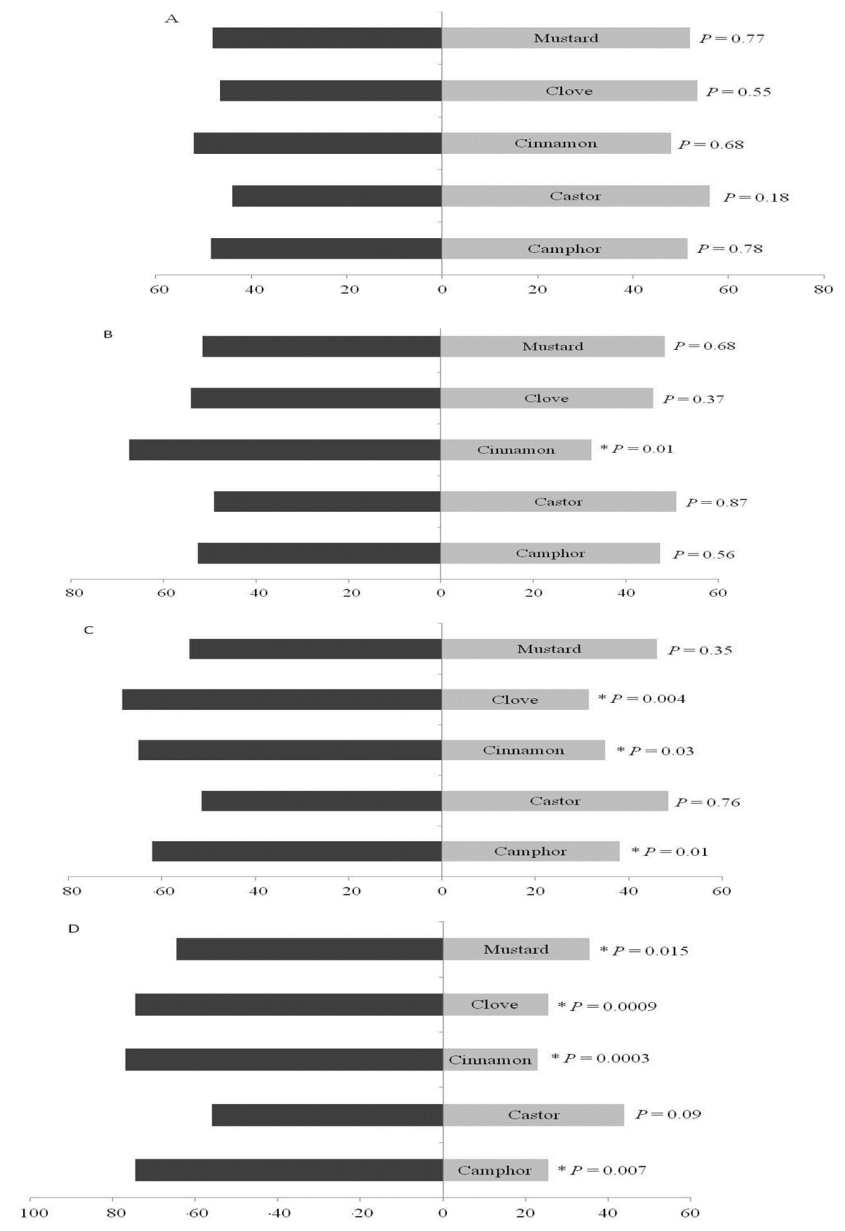

Fig. 2. Preference (\%) of Bruchidius incarnatus for a half filter paper treated or not with five essential oils with concentrations (A) 0.5 $\%$ (B) $1 \%, 2 \%$ and (c) $4 \%$ after $4 \mathrm{~h}$, in free choice test. ${ }^{*}$ Significant values at $5 \%$ probability by t-paired test $(p<0.05)$ 
Tab. 2. Essential oils, $\mathrm{LD}_{50}(\mu \mathrm{L} / \mathrm{Cm} 2)$ of Camphor, Castor, Cinnamon, Clove and Mustard on a treated surface on the faba bean beetle, Bruchidius incarnatus (Coleoptera: Bruchidae) adults

\begin{tabular}{|c|c|c|c|c|c|}
\hline Duration (h) & Oils & $\mathrm{LD}_{50}\left(\mu \mathrm{L} / \mathrm{Cm}^{2}\right)$ & Slope \pm SE & $\mathrm{X}^{2}$ & P value \\
\hline \multirow{5}{*}{$24 \mathrm{~h}$} & Camphor & $0.64(0.52-0.88)$ & $2.92 \pm 0.45$ & 66.94 & 0.003 \\
\hline & Castor & $2.08(1.20-7.60)$ & $1.82 \pm 0.40$ & 41.95 & 0.30 \\
\hline & Cinnamon & $0.52(0.43-0.65)$ & $2.22 \pm 0.25$ & 44.57 & 0.21 \\
\hline & Clove & $0.86(0.62-1.56)$ & $2.15 \pm 0.39$ & 66.08 & 0.003 \\
\hline & Mustard & $0.67(0.53-0.98)$ & $2.59 \pm 0.41$ & 69.82 & 0.001 \\
\hline \multirow{5}{*}{$48 \mathrm{~h}$} & Camphor & $0.62(0.51-0.81)$ & $2.31 \pm 0.26$ & 30.38 & 0.81 \\
\hline & Castor & $1.44(0.96-3.22)$ & $1.91 \pm 0.35$ & 28.01 & 0.88 \\
\hline & Cinnamon & $0.37(0.32-0.43)$ & $2.49 \pm 0.24$ & 44.74 & 0.21 \\
\hline & Clove & $0.50(0.42-0.61)$ & $2.43 \pm 0.26$ & 47.78 & 0.13 \\
\hline & Mustard & $0.59(0.48-0.80)$ & $2.68 \pm 0.38$ & 62.86 & 0.007 \\
\hline \multirow{5}{*}{$72 \mathrm{~h}$} & Camphor & $0.51(0.43-0.62)$ & $2.45 \pm 0.26$ & 37.59 & 0.49 \\
\hline & Castor & $1.25(0.88-2.40)$ & $2.05 \pm 0.35$ & 26.79 & 0.19 \\
\hline & Cinnamon & $0.30(0.27-0.34)$ & $2.99 \pm 0.25$ & 46.65 & 0.16 \\
\hline & Clove & $0.41(0.35-0.51)$ & $2.80 \pm 0.33$ & 57.95 & 0.02 \\
\hline & Mustard & $0.60(0.48-0.83)$ & $2.35 \pm 0.33$ & 57.72 & 0.02 \\
\hline \multirow{5}{*}{$96 \mathrm{~h}$} & Camphor & $0.46(0.39-0.55)$ & $2.47 \pm 0.26$ & 35.32 & 0.59 \\
\hline & Castor & $0.94(0.73-1.42)$ & $2.42 \pm 0.36$ & 34.39 & 0.64 \\
\hline & Cinnamon & $0.30(0.26-0.33)$ & $3.02 \pm 0.26$ & 48.87 & 0.11 \\
\hline & Clove & $0.38(0.33-0.46)$ & $3.04 \pm 0.34$ & 58.21 & 0.02 \\
\hline & Mustard & $0.55(0.46-0.73)$ & $2.71 \pm 0.37$ & 60.72 & 0.01 \\
\hline
\end{tabular}

repellent and toxic effect on $B$. incarnates adults, suggests a wide spectrum of action from these essentials oils. Cinnamon oil had a highest possess repellency as well as toxicity effects against $B$. incarnates adult followed by clove $>$ camphor $>$ mustard and a lowest possess repellency as well as toxicity effects was castor oil. Cinnamon powder also was showed generally a more repellent effective on adults of $S i$ tophilus granarius, Rhyzopertha dominica and T. castaneum (Shayesteh and Ashouri, 2010). The powders of Piper nigrum, Capsicum annuum and C. zeylanicum (Cinnamon plant) showed a repellent effect on $S$. zeamais (Salvadores et al., 2007). Cinnamaldehyde isolated from cinnamon oil was considered contact toxicity to both $T$. castaneum and S. zeamais (Huang and Ho, 1998).

The clove oil had also repellent activity on three important stored grain insect pests, $R$. dominica, $S$. oryzae and T. castaneum (Zeng et al., 2010). As well as, oil of clove is toxic to $S$. oryzae and $R$. dominica (Sighamony et al., 1986). However, extracts from clove plant had insecticidal effect to T. castaneum and S. zeamais (Ho et al., 1994), with the main chemical components of clove essential oil are phenylpropanoids such as carvacrol, thymol, eugenol, eugenol acetate, iso-eugenol and caryophyllene (Chaieb et al., 2007; Olivier et al., 1999).

The monoterpene camphor might have broad insecticidal activity against stored-product insects and act as a fumigant in Asplenium haussknechtii oil. Camphor from several Artemisia species reported that is toxic against stored-product beetles (Dunkel and Sears, 1998; Kordali et al., 2006; Negahban et al., 2007). Effect of mustard oil also has been reported on B. incarnatus (Sabbour and Abd-El-Aziz, 2010), Callosobruchus chinensis (Ali et al., 1983) and S. zeamais (Costa $e t$ al., 2006). The presence of Allyl isothiocyanate (AITC), the main toxic compound formed from allyl glucosinolate hydrolysis (Mayton et al., 1996), was considered insecticidal substance biofumigation (Noble et al., 2002). The highest concentrations of AITC are found in some mustard, horseradish and wasabi species (Olivier et al., 1999; Yu et al., 2003).

In our results, the $\mathrm{LD}_{50}$ value was decreased gradually in all the essential oils with increasing the days of exposure. This results agree with the results obtained by Arannilewa et al. (2006) whose reported that an increase of mortality of $S$. zeamais adult associated with increasing the days of exposure in all concentrations of tested essential oils. Also, Arabi et al. (2008) and Ahmed (2006) reported that mortality of $S$. oryzae and $O$. surinamensis adults, respectively, was increased with the increase of the concentrations of camphor oil and increased the time of exposure.

\section{Conclusions}

Based on the present study, it could be concluded that essential oils of cinnamon, clove, camphor and mustard pose potential repellent and toxic activity against adults of $B$. incarnatus with higher effective was found by using cinnamon oil. The study demonstrates that these essential oils can play an important role in protection of faba bean grains from adults of $B$. incarnatus. 
358

\section{References}

Abbott WS (1925). A method of computing the effectiveness of an insecticide. J Econ Entomol 18:265-267.

Ahmed MA (2006). Toxicity and repellency of seven plant essential oils to Oryzaephilus surinamensis (Coleoptera: Silvanidae) and Tribolium castaneum (Coleoptera: Tenebrionidae). Sci J King Faisal Univ., Basic and Appl Sci 7:14-27.

Ahn YJ, Lee SB, Lee HS, Kim GH (1998). Insecticidal and acaricidal activity of carvacrol and b-thujaplicine derived from Thujopsis dolabrata var. hondai sawdust. J Chem Ecol 24:8190.

Ali SI, Singh OP, Misra US (1983). Effectiveness of plant oils against pulse beetle Callosobruchus chinensis Linn. Indian J Entomol 45:6-9.

Arabi F, Moharramipour S, Sefidkon F (2008). Chemical composition and insecticidal activity of essential oil from Perovskia abrotanoides (Lamiaceae) against Sitophilus oryzae (Coleoptera: Curculionidae) and Tribolium castaneum (Coleoptera: Tenebrionidae). Int J Trop Insect Sci 28:144-150.

Arannilewa, ST, Ekrakene T, Akinneye JO (2006). Laboratory evaluation of four medicinal plants as protectants against the maize weevil, Sitophilus zeamais Mots. Afri J Biotechnol 5:2032-2036

Arthur FH (1996). Grain protectants: current status and prospects for the future. J Stored Prod Res 32:293-302.

Benzi VS, Murray AP, Ferrero AA (2009). Insecticidal and insect-repellent activities of essential oils from Verbenaceae and Anacardiaceae against Rhizopertha dominica. Natur Prod Comm 4:1287-1290.

Chaieb K, Hajlaoui H, Zmantar T, Ben Kahla-Nakbi A, Rouabhia M, Mahdouani K, Bakhrouf A (2007). The chemical composition and biological activity of clove essential oil, Eugenia caryophyllata (Syzigium aromaticum L. myrtaceae): a short review. Phytother Res 21(6):501-506.

Costa RR, Sousa AH, Faroni LRDA, Dhingra OD, Pimentel MAG (2006). Toxicity of mustard essential oil to larvae and pupas of Sitophilus zeamais (Coleoptera: Curculionidae). Proc Con Stored Prodt Prot 9:908-913.

Dunkel FV, Sears LJ (1998). Fumigant properties of physical preparations from mountain big sagebrush, Artemisia annua Nutt., ssp vaseyana (Rydb.) Beetle for stored grain insects. J Stored Prod Res 34:304-321.

Finney DJ (1971). Probit Analysis. Cambridge University Press, London, $333 \mathrm{p}$.

Fouad HA, Faroni LRDA, Ribeiro C, Tavares WD, Petacci F (2012). Extraction and repellent activity of Lepidoploa aurea and Memora nodosa against stored grain and byproduct pests. Vie Milieu 62:11-15.

Ho SH, Cheng PLP, Sim KY, Tan HTW (1994). Potential of cloves (Syzygium aromaticum (L.) Merr. \& Perry) as a grain protectant against Tribolium castaneum (Herbst) and Sitophilus zeamais Motsch. Postharvest Biol Technol 4:179183.
Huang Y, Ho SH (1998). Toxicity and antifeedant activities of cinnamaldehyde against the grain storage insects, Tribolium castaneum (Herbst) and Sitophilus zeamais Motsch. J Stored Prod Res 34:11-17.

Juliana G, Su HCF (1983). Laboratory studies on several plant materials as insect repellents for protection of cereal grains. J Econ Entomol 76:154-157.

Kordali S, Aslan I, Calmasur O, Cakir A (2006). Toxicity of essential oils isolated from three Artemisia species and some of their major components to granary weevils, Sitophilus granarius (L) (Coleoptera: Curculionidae). Ind Crop Prod 23:162-170.

Mahfuz I, Khalequzzaman M (2007). Contact and fumigant toxicity of essential oils against Callosobruchus maculatus. University journal of zoology Rajshahi Univ 26:63-66.

Mahmoudvand M, Abbasipour H, Hosseinpour MH, Rastegar F, Basij M (2011). Using some plant essential oils as natural fumigants against adults of Callosobruchus maculatus (F.) (Coleoptera: Bruchidae). Mun Ent Zool 6:150-154.

Mayton HS, Olivier C, Vaughn SF, Loria R (1996). Correlation of fungicidal activity of Brassica species with allyl isothiocyanate production in macerated leaf tissue. J Phytopathol 86:267-271.

Negahban M, Moharramipour S (2007). Fumigant toxicity of Eucalyptus intertexta, Eucalyptus sargentii and Eucalyptus camaldulensis against stored-product beetles. J Appl Entomol 131:256-261.

Noble RRP, Harvey SG, Sams CE (2002). Toxicity of Indian mustard and allyl isothiocyanate to masked chafer beetle larvae. Plant Health Progress www.plantmanagementnetwork. org/pbu/php/research/chafer/. Retrieved June 2006.

Obeng-Ofori D, Reichmuth CH (1997). Bioactivity of eugenol, a major component of essential oil of Ocimum suave (Wild.) against four species of stored product Coleoptera. Int J Pest Manag 43:89-94.

Olivero-Verbel J, Nerio LS, Stashenko EE (2010). Bioactivity against Tribolium castaneum Herbst (Coleoptera: Tenebrionidae) of Cymbopogon citratus and Eucalyptus citriodora essential oils grown in Colombia. Pest Manag Sci 66:664-668.

Olivier C, Vaughn SF, Mizubuti ESG, Loria R (1999). Variation in allyl isothiocyanate production within Brassica species and correlation with fungicidal activity. J Chem Ecol 25:2687-2701.

Pimentel MAG, Faroni LRDA, Guedes RNC, Sousa AH, Tótola MR (2009). Phosphine resistance in Brazilian populations of Sitophilus zeamais Motschulsky (Coleoptera: Curculionidae). J Stored Prod Res 45:71-74.

Potenza MR, Arthur V, Felicio JD, Rossi MH, Sakita MN, Silvestre DF, Gomes DHP (2004). Efeito de produtos naturais irradiados sobre Sitophilus zeamais Mots. (Coleoptera: Curculionidae). Arq Inst Biol 71:477-484.

Regnault-Roger C, Hamraoui A (1995). Fumigant toxic activity and reproductive inhibition induced by monoterpenes 
on Acanthoscelides obtectus (Say) (Coleoptera), a bruchid of kidney bean (Phaseolus vulgaris L.). J Stored Prod Res 31:291-299.

Sabbour Magda M, Abd-El-Aziz SE (2010). Efficacy of some bioinsecticides against Bruchidius incarnatus (Boh.) (Coleoptera: Bruchidae) infestation during storage. J Plant Prot Res 50:28-34.

Salvadores YU, Silva GA, Tapia MV, Hepp RG (2007). Spices powders for the control of maize weevil, Sitophilus zeamais Motschulsky, in stored wheat. Agricultura Tecnica 67:147154.

Santos JC, Faroni LRDA, Simões RO, Pimentel MAG Sousa AH (2009). Toxicity of pyrethroids and organophosphorus insecticides to Brazilian populations of Sitophilus zeamais (Coleoptera: Curculionidae). Biosci J 25:75-81.

SAS Institute SAS (2002). User's guide: statistics. SAS Institute Cary, NC, USA, 9:6166-6260.

Shayesteh N, Ashouri S (2010). Effect of four powdered spices as repellents against adults of Rhyzopertha dominica (F.), Sitophilus granarius (L.) and Tribolium castaneum (Herbst) in laboratory conditions. Proc Conf Stored Prod Prot 10:799804.

Sighamony S, Anees I, Chandrakala TS, Osmani Z (1986). Efficacy of certain indigenous plant products as grain protectants against Sitophilus oryzae (L.) and Rhyzopertha dominica (F.). J Stored Prod Res 22:21-23.
Tapondjou AL, Adler C, Fontem DA, Bouda H, Reichmuth C (2005). Bioactivities of cymol and essential oils of Cupressus sempervirens and Eucalyptus saligna against Sitophilus zeamais Motschulsky and Tribolium confusum du Val. J Stored Prod Res 41:91-102.

Tavares WS, Costa MA, Cruz I, Silveira RD, Serrão JE, Zanuncio JC (2010). Selective effects of natural and synthetic insecticides on mortality of Spodoptera frugiperda (Lepidoptera: Noctuidae) and its predator Eriopis connexa (Coleoptera: Coccinellidae). J Environ Sci Health B 45:557-561.

Tinkeu L, Goudoum SN, Ngassoum A, Mapongmetsem MB, Kouninki PM, Hance T (2004). Persistence of the insecticidal activity of five essential oils on the maize weevil $\mathrm{Si}$ tophilus zeamais (Motsch.) (Coleoptera: Curculionidae). Commun Agric Appl Biol Sci 69:145-147.

Yu JC, Jiang ZT, Li R, Chan SM (2003). Chemical composition of the essential oils of Brassica juncea (L.) Coss. grown in different regions, Hebei, Shaanxi and Shandong, of China. J Food Drug Anal 11:22-26.

Zeng L, Lao CZ, Cen YJ, Liang GW (2010). Study on the insecticidal activity compounds of the essential oil from Syzygium aromaticum against stored grain insect pests. Proc Conf Stored Prod Prot, 10:766-771. 